\title{
Exogenous essential amino acids stimulate an adaptive unfolded protein response in the mammary glands of lactating cows
}

\author{
K. Nichols, ${ }^{* 1}$ J. Doelman, $\dagger^{2}$ J. J. M. Kim, ${ }^{*}$ M. Carson, $\dagger$ J. A. Metcalf, $\dagger$ and J. P. Cant ${ }^{* 3}$ \\ *Department of Animal Biosciences, University of Guelph, ON, N1G 2W1 Canada \\ †Trouw Nutrition Agresearch Canada, Guelph, ON, N1G 4T2 Canada
}

\begin{abstract}
The phosphorylation of mammalian target of rapamycin complex 1 (mTORC1) components and integrated stress response networks in the mammary glands of lactating cows have not accounted for the stimulation of milk protein yield by chronic supplementation with AA or glucose. Faster milk protein synthesis could be a consequence of increased milk protein mRNA per cell, the number of ribosomes per cell, the secretory capacity of cells, or the mammary cell number. To investigate these 4 possibilities using a translational and transcriptional approach, we performed protein and gene expression analyses of mammary and longissimus dorsi tissue collected from lactating dairy cows after $5 \mathrm{~d}$ of abomasal infusion with saline or 844 or $1,126 \mathrm{~g} / \mathrm{d}$ of an essential AA (EAA) mixture, with and without 1,000 g/d glucose. Infusion with EAA increased milk protein yield but did not affect the phosphorylation of mTORC1related proteins in the mammary gland. In skeletal muscle, phosphorylation of 4EBP1 (eIF4E-binding protein 1) increased in response to both EAA and glucose, and phosphorylated S6K1 (70-kDa ribosomal protein S6 kinase) increased with glucose. In response to EAA, mammary mRNA expression of the marker genes for milk proteins, ribosome biogenesis, and cell proliferation were not upregulated. Instead, reciprocal regulation of 2 arms of the unfolded protein response occurred. Infusion of EAA for 5 d activated XBP1 (Xbox binding protein 1) mRNA, encoding a transcription factor for endoplasmic reticulum biogenesis, and it decreased the mRNA expression of genes encoding pro-apoptotic protein CHOP (C/EBP homologous protein) and downstream GADD34 (growth arrest and DNA damage-inducible 34). These findings implicate

Received December 1, 2016.

Accepted March 23, 2017.

${ }^{1}$ Current address: Animal Nutrition Group, Wageningen University, PO Box 338, the Netherlands.

${ }^{2}$ Current address: Trouw Nutrition R\&D, Veerstraat 38, 5831 JN Boxmeer, the Netherlands.

${ }^{3}$ Corresponding author: jcant@uoguelph.ca.
\end{abstract}

non-stress-related, adaptive capabilities of the unfolded protein response in the long-term nutritional regulation of milk protein yield in lactating dairy cows.

Key words: mammary, mammalian target of rapamycin complex 1 (mTORC1), unfolded protein response, milk synthesis

\section{INTRODUCTION}

The synthesis of secretory milk proteins in the mammary glands of lactating dairy cows is highly regulated, energy demanding, and responds to nutritional status. Increases in either dietary energy or protein intake can stimulate milk protein yield (Rius et al., 2010) by improving the supply of EAA and relaying anabolic signals such as insulin to the mammary glands (Metcalf et al., 1996; Bequette et al., 2002; Doepel and Lapierre, 2010). The intracellular mechanisms by which circulating AA, glucose, and insulin stimulate milk protein yield from the mammary glands remain incompletely understood.

It is well established that signaling through mammalian target of rapamycin complex 1 (mTORC1) is responsible for EAA- and insulin-mediated upregulation of protein synthesis in the skeletal muscle and liver of young, growing animals after a meal (Kimball et al., 2000; O'Connor et al., 2003; O'Connor et al., 2004). In mammary epithelial cells in vitro, mTORC1 is activated by EAA and the intracellular kinase Akt (protein kinase B) upon insulin or insulin-like growth factor 1 stimulation (Moshel et al., 2006; Burgos et al., 2010; Appuhamy et al., 2011) and is inhibited by AMP-activated protein kinase (Burgos et al., 2013). In vivo, in underfed dairy cows that have been intensively selected for high milk production, mammary mTORC1 is stimulated by a combination of EAA plus glucose within 36 h (Rius et al., 2010; Toerien et al., 2010). Infusion of glucose without AA into fasted cows for $9 \mathrm{~h}$ enhanced milk protein yield but failed to activate mTORC1, instead inhibiting phosphorylation of eukaryotic initiation factor (eIF) $2 \alpha$ (Toerien et al., 2010), a second messenger of the integrated stress response (ISR), which is an alternative pathway that exerts translational control (Proud, 2005). 
In contrast to these acute mammary responses, the effects of chronic perturbations of cows' nutritional status by several days of EAA infusion have not proven to be consistent with the canonical translation regulation pathways. Infusion of complete EAA mixtures for $5 \mathrm{~d}$ increased mammary mTORC1 signaling in one study (Doelman et al., 2015a) but not in another (Doelman et al., 2015b). Imbalanced EAA mixtures lacking 1 EAA were expected to increase eIF $2 \alpha$ phosphorylation via the ISR that downregulates protein synthesis during nutrient insufficiency, but the imbalances had no effect on the phosphorylation state of mammary eIF $2 \alpha$ and they stimulated mTORC1 signaling without increasing milk protein yield (Doelman et al., 2015a; Doelman et al., 2015b). These responses suggest that factors other than mTORC1 and ISR signaling may be responsible for the control of milk protein synthesis. We hypothesized that acute and transient phosphorylation-level control of the mRNA translation rate is replaced by transcriptional control in mammary cells during chronic elevation of nutritional status.

To elucidate potential pathways that mediate the long-term effects of nutritional status on milk protein yield, we measured the abundance and phosphorylation states of proteins involved in the regulation of mRNA translation, and the expression of genes related to translation, ribosome biogenesis, endoplasmic reticulum (ER) homeostasis, and cell turnover in mammary tissue of cows infused abomasally with EAA and glucose for $5 \mathrm{~d}$. We found that components of the unfolded protein response (UPR) were involved in the nutritional regulation of milk protein yield in a manner consistent with non-stress-related differentiation of the secretory phenotype.

\section{MATERIALS AND METHODS}

\section{Experimental Protocol and Sampling}

All experimental procedures were approved by the Animal Care and Use Committee at Trouw Nutrition Agresearch, adhering to guidelines set forth by the Canadian Council on Animal Care (2009). Five rumenfistulated, multiparous (2.4 \pm 0.5 lactations) Holstein cows producing an average of $33.0 \mathrm{~kg} / \mathrm{d}$ milk at $78 \pm$ $13 \mathrm{DIM}$ and $576 \pm 70.3 \mathrm{~kg}$ of BW were randomly assigned to a $5 \times 5$ Latin square design in which each period consisted of a 5 -d continuous abomasal infusion followed by $2 \mathrm{~d}$ of rest. Cows were housed in tie stalls with individual free access to water and milked twice daily at 0500 and $1600 \mathrm{~h}$. Cows were acclimated to a corn-silage-based TMR (6.94 MJ/kg of net energy and $12.4 \% \mathrm{CP}$ on a DM basis) for $14 \mathrm{~d}$ before the start of the experiment and were fed once daily at $0700 \mathrm{~h}$ for the duration of the experiment at a fixed intake. Details of the diet are given in a companion paper (Nichols et al., 2016).

Infusion lines were placed in the abomasum via the rumen cannula $1 \mathrm{~d}$ before the first experimental period and were checked daily for patency. Infusion treatments were $0.9 \%$ saline (SAL) or complete mixtures of EAA with the same profile and amount as found in 1,500 and 2,000 g/d casein according to Metcalf et al. (1996), with or without the inclusion of $1,000 \mathrm{~g} / \mathrm{d}$ of glucose (1.5EAA, 2EAA, 1.5+GLC, and 2+GLC, respectively). Treatment solutions were prepared daily in 10-L batches and were infused using a Watson-Marlow 205U/CA multi-channel peristaltic pump (Wilmington, MA) at a rate of $6.95 \mathrm{~mL} / \mathrm{min}$, delivering 884 and $1,126 \mathrm{~g} / \mathrm{d}$ EAA for the 1.5EAA and 2EAA treatments, respectively. Amino acids were infused at the following rates $(\mathrm{g} / \mathrm{d})$ for the $1.5 \mathrm{EAA}$ and $2 \mathrm{EAA}$ treatments, respectively: L-Arg (59 and 78), L-His (48 and 64), LIle (86 and 115), L-Val (96 and 128), L-Leu (141 and 188), L-Phe (141 and 188), DL-Met (41 and 55), L-Lys (147 and 196), L-Thr (63 and 85), and L-Trp (21 and 28). Milk sampling and composition analysis were as described by Nichols et al. (2016).

On d 5 of each infusion period, muscle tissue was collected by biopsy according to Nichols et al. (2016) from the left or right longissimus dorsi muscle. Immediately following the muscle biopsies, approximately $500 \mathrm{mg}$ of mammary tissue were also collected by biopsy according to Toerien et al. (2010) from the left or right rear quarters of the udder. The first quarter for biopsy was randomly selected, and quarters were alternated in each successive period. Before incision, $5 \mathrm{~mL}$ of lidocaine was injected subcutaneously at the biopsy site. Mammary and muscle samples were immediately rinsed in saline, snap frozen in liquid $\mathrm{N}_{2}$, and stored at $-80^{\circ} \mathrm{C}$ until analysis. A nonsteroidal anti-inflammatory drug (ketoprofen, $3 \mathrm{mg} / \mathrm{kg}$ of BW) was administered intramuscularly after both biopsy procedures to provide analgesia and minimize inflammation.

\section{Western Blot Analysis}

Approximately $50 \mathrm{mg}$ each of muscle and mammary tissue were homogenized for $10 \mathrm{~s}$ in $0.5 \mathrm{~mL}$ of lysis buffer (1\% Triton X-100, 0.1\% SDS, $50 \mathrm{~m} M$ Tris-HCl pH $8.0,150 \mathrm{mM} \mathrm{NaCl}$, and $0.5 \%$ sodium deoxycholate) containing protease and phosphatase inhibitors (Thermo Scientific, Nepean, ON, Canada). Homogenates were inverted for $1 \mathrm{~h}$ at $4^{\circ} \mathrm{C}$, and then centrifuged at 13,000 $\times g$ for 20 min at $4^{\circ} \mathrm{C}$. Mammary and muscle supernatants were diluted with lysis buffer to $1.5 \mu \mathrm{g} / \mu \mathrm{L}$ and 3 $\mu \mathrm{g} / \mu \mathrm{L}$, respectively, and diluted to a final concentration 
of $0.75 \mu \mathrm{g} / \mu \mathrm{L}$ and $1.5 \mu \mathrm{g} / \mu \mathrm{L}$, respectively, with sample buffer (4\% SDS, $20 \%$ glycerol, $10 \% \beta$-mercaptoethanol, $0.125 \mathrm{M}$ Tris- $\mathrm{HCl}$ and $0.004 \%$ bromophenol blue), before boiling at $90^{\circ} \mathrm{C}$ for $5 \mathrm{~min}$. Then, $20 \mu \mathrm{L}$ of boiled mammary sample and $10 \mu \mathrm{L}$ of boiled muscle sample, both containing $15 \mu \mathrm{g}$ of total protein and BLUeye Prestained Protein Ladder (FroggaBio, Toronto, ON, Canada) were separated by 6,8 , or $12 \%$ SDS-PAGE according to protein size at $120 \mathrm{~V}$ for approximately 90 min. Proteins were electrotransferred (Mini Trans-Blot, BioRad Laboratories Inc., Mississauga, ON, Canada) onto polyvinylidene difluoride membranes (Millipore, Mississauga, ON, Canada) at $100 \mathrm{~V}$ for $60 \mathrm{~min}$. Membranes were incubated at room temperature for $1 \mathrm{~h}$ in Tris-buffered saline-Tween (TBST) buffer containing $5 \%$ nonfat dry milk before incubation at room temperature with rabbit or mouse monoclonal antibodies against phosphorylated and total Akt (9271 and 9272), AMPK $\alpha$ (2535 and 5831), eIF4E-binding protein 1 (4EBP1; 9451 and 9452), 70-kDa ribosomal protein S6 kinase 1 (S6K1; 9206 and 2708), protein kinase R-like endoplasmic reticulum kinase (PERK; 3179 and 3192), eIF2 $\alpha$ (3597 and 5324XP), and eIF2B $\varepsilon$ (ab4775 and 3595). All antibodies were purchased from Cell Signaling Technologies Inc. (Danvers, MA), with the exception of phosphorylated eIF2B $\varepsilon$, which was purchased from Abcam (Cambridge, MA). All primary antibodies were diluted using 1\% milk TBST buffer. Membranes were rinsed with TBST buffer and incubated at room temperature for $1 \mathrm{~h}$ with horseradish peroxidase-linked anti-rabbit or anti-mouse IgG (rabbit: NA934V, GE Healthcare Life Sciences, Mississauga, ON, Canada; mouse: 7076, Cell Signaling Technologies Inc.) diluted in TBST buffer. Following six 5-min washes of the membranes in TBST buffer, proteins were developed using chemiluminescence (Clarity Western ECL Substrate, BioRad). All membranes first probed with proteins of interest underwent three 5-min washes in TBST buffer and appropriate portions were re-probed with antibodies against $\beta$-actin (ab6276, Abcam) in mammary tissue or glyceraldehyde 3-phosphate dehydrogenase (GAPDH; ab8245, Abcam) in muscle tissue as loading controls. Blot densities in scanned images were determined by ImageLab software (BioRad) and normalized to the corresponding loading control blot density. The phosphorylation state of each protein was calculated as the ratio of phosphorylated to total blot densities (see Figures 3 and 4 for representative Western blot images of all proteins analyzed).

\section{Real-Time Quantitative PCR}

Total RNA was isolated from approximately 100 mg each of mammary and muscle tissue using $1 \mathrm{~mL}$ of TRIzol Reagent (Invitrogen, Life Technologies, Burlington, ON, Canada) according to the manufacturer's instructions. Genomic DNA was removed with DNase (Invitrogen) according to the manufacturer's instructions. Quality of RNA was determined by electrophoretic analysis of $28 \mathrm{~S}$ and $18 \mathrm{~S}$ subunits with a $1 \%$ agarose TBE gel (40 $\mathrm{m} M$ Tris base, $40 \mathrm{~m} M$ boric acid, $0.2 \% 0.5 M$ EDTA pH 8.0) by staining with ethidium bromide and was quantified using an Agilent 2100 Bioanalyzer (Agilent Technologies, Mississauga, ON, Canada). Samples that produced an RNA integrity number $>7$ were considered acceptable for use. Primers (Integrated DNA Technologies, Coralville, IA) were designed to yield PCR amplification products of 100 to 200 bp (Table 1) with efficiency greater than $90 \%$. The cDNA was synthesized from $500 \mathrm{ng}$ of extracted total RNA with random hexamers using a High Capacity cDNA Reverse Transcription Kit (Applied BioSystems, Waltham, MA), following the manufacturer's instructions, and were stored at $-80^{\circ} \mathrm{C}$ until further analysis. The qPCR was carried out using $5 \mu \mathrm{L}$ of diluted cDNA combined with a $15-\mu \mathrm{L}$ mixture composed of $10 \mu \mathrm{L}$ of PerfeCTa SYBR Green FastMix (Quanta BioSciences, Gaithersburg, MD), $0.4 \mu M$ forward and reverse primers, and DNase-/RNase-free water with an Applied Biosystems 7300 real-time PCR instrument.

We chose the most stably expressed genes of the 27 analyzed in mammary tissue and 7 in skeletal muscle to use as references for normalization by analyzing variance in cycle threshold $(\mathbf{C t})$ value due to cow, period, and treatment. For each gene, a coefficient of variation was calculated by dividing the total sum of squares due to cow + period + treatment by degrees of freedom of 12 and the mean $\mathrm{Ct}$ value. The genes with the lowest coefficient of variation were RPS6KB1 for mammary tissue and $B C K D H A$ for skeletal muscle. Fold changes in gene expression relative to saline were calculated by the $2^{\Delta \Delta \mathrm{Ct}}$ method (Livak and Schmittgen, 2001), using RPS6KB1 and BCKDHA expression as the respective reference genes.

\section{Statistical Analysis}

Variances in natural log-transformed protein abundance and gene expression data were analyzed using the MIXED procedure of SAS (version 9.2; SAS Institute Inc., Cary, NC) with cow as a random effect and period and infusion treatment as fixed effects. The effects of EAA were estimated as linear contrasts of $0,1.5 \mathrm{EAA}$, and 2EAA without glucose, using coefficients matched to the EAA dose from PROC IML of SAS. The effects of 1.5+GLC and 2+GLC (GLC) were estimated from orthogonal contrasts between EAA treatments with and without glucose. Differences were considered significant 
Table 1. Primer sequences for quantitative real-time PCR in bovine mammary and muscle tissue ${ }^{1}$

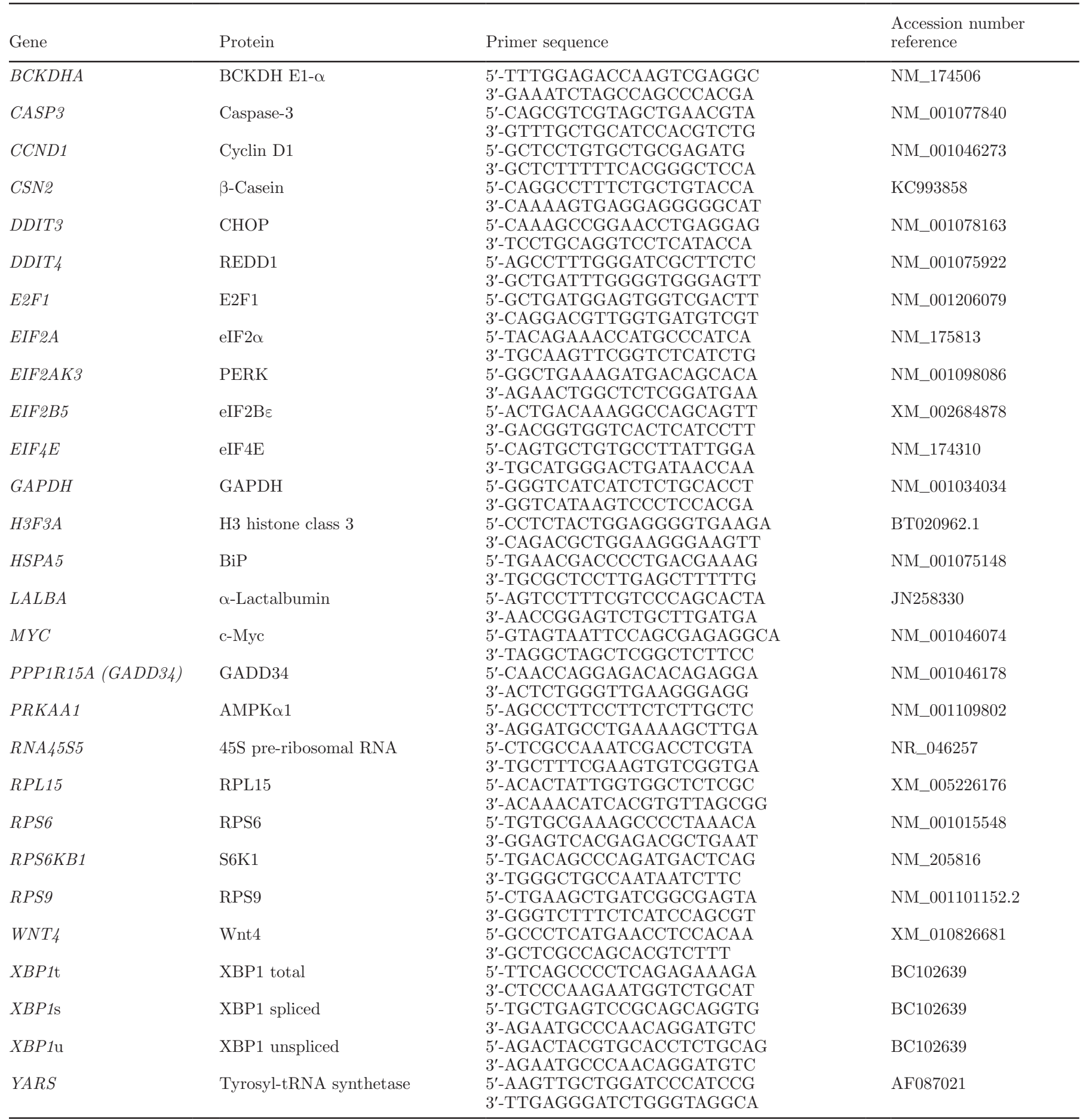

${ }^{1}$ BCKDH E1- $\alpha=$ branched-chain keto-acid dehydrogenase e1, $\alpha$ subunit; CHOP $=\mathrm{C} /$ EBP homologous protein; DDIT3 $=$ DNA damageinducible transcript 3; DDIT4 = DNA damage-inducible transcript 4; REDD1 = regulated in DNA damage and development 1; E2F1 = E2F transcription factor 1; eIF $2 \alpha=$ eukaryotic initiation factor 2, $\alpha$ subunit; PERK = protein kinase RNA-like endoplasmic reticulum kinase; eIF2B $\varepsilon$ $=$ eukaryotic initiation factor $2 \mathrm{~B}, \varepsilon$ subunit; eIF4E = eukaryotic initiation factor 4E; GAPDH = glyceraldehyde 3-phosphate dehydrogenase; HSPA5 = heat-shock protein A5; BiP/GRP78 = 78 kDa glucose-regulated protein; c-Myc $=$ v-myc avian myelocytomatosis viral oncogene homolog; PPP1R15A = protein phosphatase 1 regulatory subunit 15A; GADD34 = growth arrest and DNA damage-inducible 34; AMPK $\alpha$ $=\mathrm{AMP}$-activated protein kinase, $\alpha$ subunit; RN45S5 = 45S ribosomal RNA; RPL15 = ribosomal protein L15; RPS6 = ribosomal protein S6; S6K1 = 70-kDa ribosomal protein S6 kinase; RPS9 = ribosomal protein S9; Wnt4 = wingless-type MMTV integration site family member 4; $\mathrm{XBP} 1=\mathrm{X}$-box binding protein 1. 
at $P \leq 0.05$ and tendencies at $0.05<P \leq 0.15$. Tukey's test detected no significant differences between 1.5EAA and 2EAA. Interactions between EAA and GLC were not estimable due to the incomplete factorial arrangement of the experiment.

\section{RESULTS}

\section{Animal Health and Production}

We observed no carryover effects on milk and milk component production between periods, assessed by testing for an effect of the previous treatment in the ANOVA. Treatment effects on yield and composition of milk collected during the last $2 \mathrm{~d}$ of infusion from the front, non-biopsied quarters of the udder were not different from those determined for milk collected from the rear, biopsied quarters (Nichols et al., 2016). Thus, results from the entire udder are presented. Milk yield increased $14 \%$ with EAA $(P<0.01)$ and tended to increase an additional $4 \%$ with GLC $(P=0.06$; Table 2$)$. Milk protein content increased 0.40 percentage points in response to EAA $(P<0.01)$ and tended to decrease with the addition of GLC $(P=0.10)$. Compared with SAL, milk protein yield increased $256 \mathrm{~g} / \mathrm{d}$, or $29 \%$, with EAA infusions $(P<0.01)$. Milk protein yield did not increase further with GLC.

\section{Translational Activity}

Infusion of EAA increased the total abundance of S6K1 in mammary tissue $46 \%(P=0.01$; Figure 1A) and tended to increase phosphorylated S6K1 abundance $35 \%(P=0.09)$, but had no effect on the phosphorylation state of S6K1. We did observe tendencies for EAA to increase the phosphorylation state of $\operatorname{eIF} 2 \mathrm{~B} \varepsilon(P=$ 0.12 ; Figure $1 \mathrm{~B})$, decrease total Akt abundance $(P=$ 0.11; Figure 1C), and decrease phosphorylated AMPK $\alpha$ abundance $(P=0.11$; Figure 1D). The addition of GLC to EAA tended to decrease total eIF2 $\alpha$ abundance $21 \%$
$(P=0.07 ;$ Figure $1 \mathrm{E})$, increase phosphorylated eIF2 $\alpha$ abundance $45 \%(P=0.09)$, and double the phosphorylation state of eIF2 $\alpha(P=0.08)$. Abundances of total and phosphorylated PERK and 4EBP1 were not affected by EAA or GLC (data not shown).

In skeletal muscle, EAA increased the phosphorylation state of $4 \mathrm{EBP} 1$ by $41 \%(P=0.02$; Figure $2 \mathrm{~A})$ and tended to increase the phosphorylation state of eIF2B $\varepsilon$ by $19 \%(P=0.11$; Figure $2 \mathrm{~B})$ and the total abundance of AMPK $\alpha$ by $51 \%(P=0.14$; Figure $2 \mathrm{C})$ over SAL. Addition of GLC to EAA infusion tended to further increase the phosphorylation state of $4 \mathrm{EBP} 1$ by $16 \%$ compared with EAA infusion alone $(P=0.12)$, and phosphorylated S6K1 abundance tended to increase by $17 \%(P=0.12$; Figure 2D $)$. The abundances of eIF2 $\alpha$ and Akt were not affected by EAA or GLC treatments (data not shown).

\section{mRNA Expression}

According to an ANOVA, the gene expressed most stably in mammary tissue across cow, period, and treatment was RPS6KB1, encoding S6K1, followed by EIF2AK3, encoding PERK. Eisenberg and Levanon (2013) also identified these 2 genes as being uniformly expressed across human tissues and potentially suitable for real-time quantitative PCR normalization. Common normalization genes GAPDH, H3F3A, and RPS9 were ranked 21st, 9th, and 23rd for stability, respectively, of the 27 genes evaluated in mammary tissue and they were also not on the list of 3,804 housekeeping genes compiled by Eisenberg and Levanon (2013). We calculated $2^{\triangle \Delta \mathrm{Ct}}$ values for mammary gene expression using RPS6KB1 expression for normalization. Gene expression in skeletal muscle was expressed relative to $B C K D H A$, which was least variable across cow, period, and treatment and has been listed as a housekeeping gene (Eisenberg and Levanon, 2013).

The expression of mTORC1- and ISR-related genes in mammary tissue was unaffected by EAA and GLC infusion (Table 3; Figure 3). In muscle, EAA had no

Table 2. Milk protein production from lactating dairy cows $(n=5)$ receiving abomasal infusions of EAA and glucose $\left(\right.$ GLC) for $5 \mathrm{~d}^{1}$

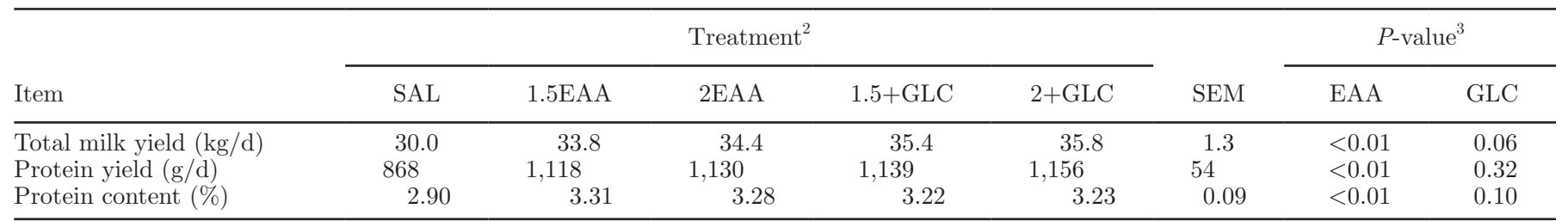

${ }^{1}$ Data are least squares means from the final $2 \mathrm{~d}$ of each period. Table has been adapted and reprinted from Nichols et al. (2016) with permission.

${ }^{2}$ Infusion treatments were $0.9 \%$ saline (SAL), or complete mixtures of EAA with the same profile as found in 1,500 and 2,000 g of casein according to Metcalf et al. (1996), with or without the inclusion of 1,000 g of glucose (1.5EAA, 2EAA, 1.5+GLC, and 2+GLC, respectively).

${ }^{3} \mathrm{EAA}=$ linear effect of EAA without GLC; GLC $=$ effect of GLC 

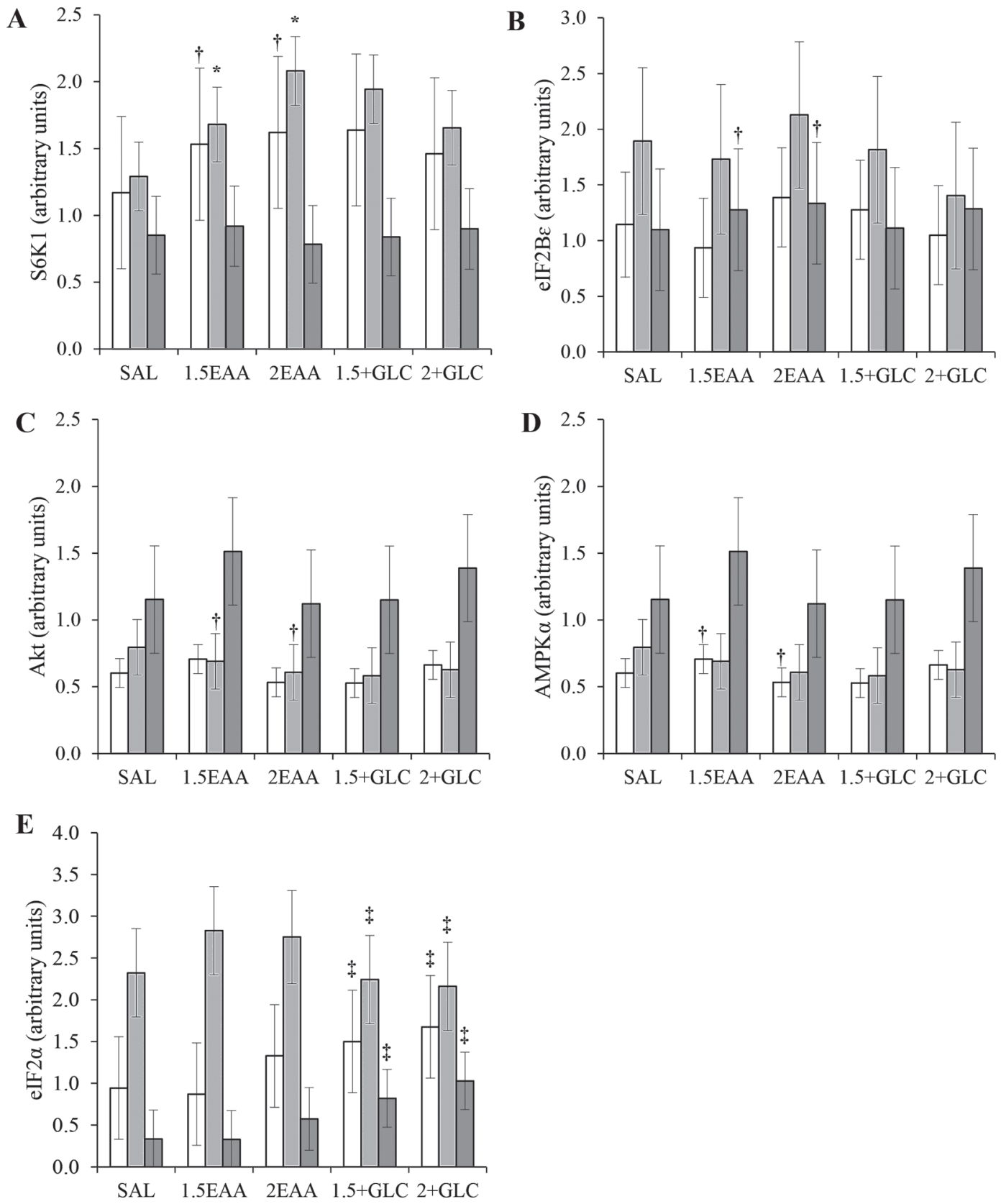

Figure 1. Protein abundances of (A) S6K1 (70-kDa ribosomal protein S6 kinase), (B) eIF2B $\varepsilon$ (eukaryotic initiation factor 2B, $\varepsilon$ subunit), (C) Akt (protein kinase B), (D) AMPK $\alpha$ (AMP-activated protein kinase, $\alpha$ subunit), and (E) eIF2 $\alpha$ (eukaryotic initiation factor 2, $\alpha$ subunit) in mammary tissue of lactating dairy cows after $5 \mathrm{~d}$ of abomasal infusion of $0.9 \%$ saline (SAL) or complete mixtures of EAA equivalent to 1,500 and $2,000 \mathrm{~g} / \mathrm{d}$ casein, with or without the inclusion of $1,000 \mathrm{~g} / \mathrm{d}$ glucose (1.5EAA, 2EAA, 1.5+GLC, and 2+GLC, respectively). Blot densities were normalized to $\beta$-actin. The phosphorylation state of each protein was calculated as the ratio of phosphorylated to total blot densities. Values are least squares means $\pm \mathrm{SE}(\mathrm{n}=5)$. ${ }^{*} P_{\mathrm{EAA}}<0.05 ; \dagger 0.05<P_{\mathrm{EAA}} \leq 0.15 ; \ddagger 0.05<P_{\mathrm{GLC}} \leq 0.15$.

effect on mTORC1- and ISR-related gene expression. Addition of GLC to EAA increased EIF4E expression $41 \%(P=0.04)$ and tended to increase EIF2A $(P=$ $0.12)$ and $P R K A A 1$ expression $(P=0.12) 20$ and $24 \%$, respectively (Table 4; Figure 4).
The expression of milk protein genes in mammary tissue was not affected by EAA or GLC (Table 5). The gene for the small ribosomal subunit protein RPS6 showed less expression after EAA treatment, but the change was small, and the other ribosomal protein 
Table 3. Mammary gland expression (arbitrary units) of genes related to mammalian target of rapamycin complex 1 (mTORC1) and the integrated stress response network in lactating dairy cows receiving abomasal infusions of EAA and glucose (GLC) for $5 \mathrm{~d}^{1}$

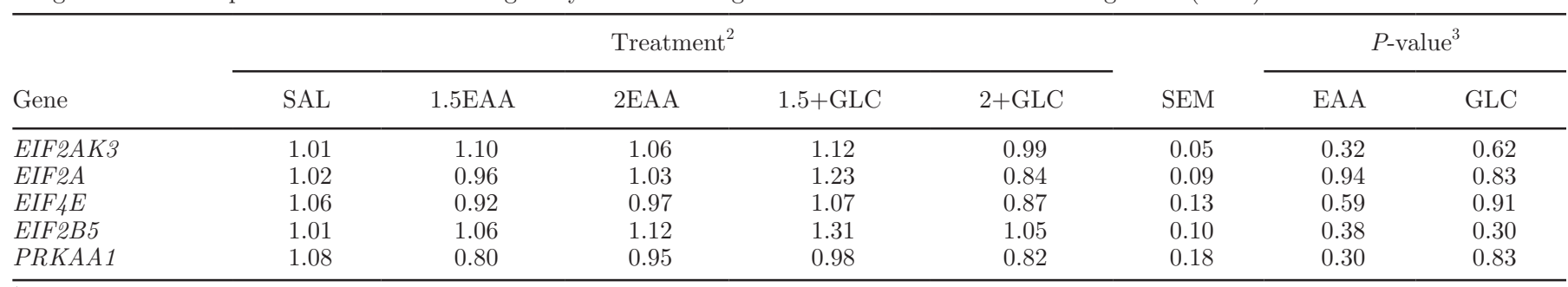

${ }^{1}$ Values are least squares means $(\mathrm{n}=5)$ from mammary tissue collected on $\mathrm{d} 5$ of each period. Fold changes in gene expression relative to SAL were calculated by the $2^{\Delta \Delta \mathrm{Ct}}$ method after normalizing to RPS6KB1.

${ }^{2}$ Infusion treatments were $0.9 \%$ saline (SAL), or complete mixtures of EAA with the same profile as found in 1,500 and 2,000 g of casein according to Metcalf et al. (1996), with or without the inclusion of 1,000 g of glucose (1.5EAA, 2EAA, 1.5+GLC, and 2+GLC, respectively).

${ }^{3} \mathrm{EAA}=$ linear effect of EAA without GLC; GLC $=$ effect of GLC.

gene transcripts and their precursor $R N A 45 S 5$ were not affected. Activating transcription factor 4 (ATF4)regulated DDIT3 $(P<0.01)$ and PPP1R15A $(P=$
0.03 ) expression decreased 40 and $30 \%$, respectively, with EAA infusion. The expression of total $(\mathrm{t})$, spliced $(\mathrm{s})$, and unspliced $(\mathrm{u})$ XBP1 was not affected by EAA

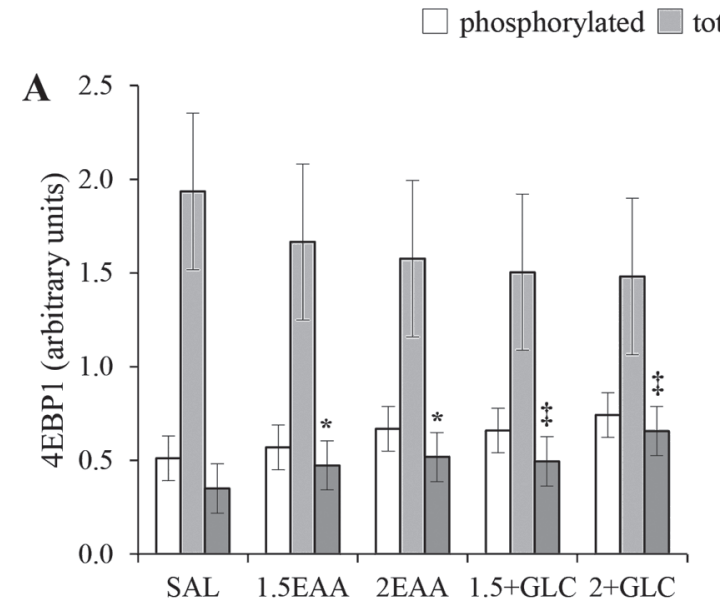

$\square$ phosphorylation state
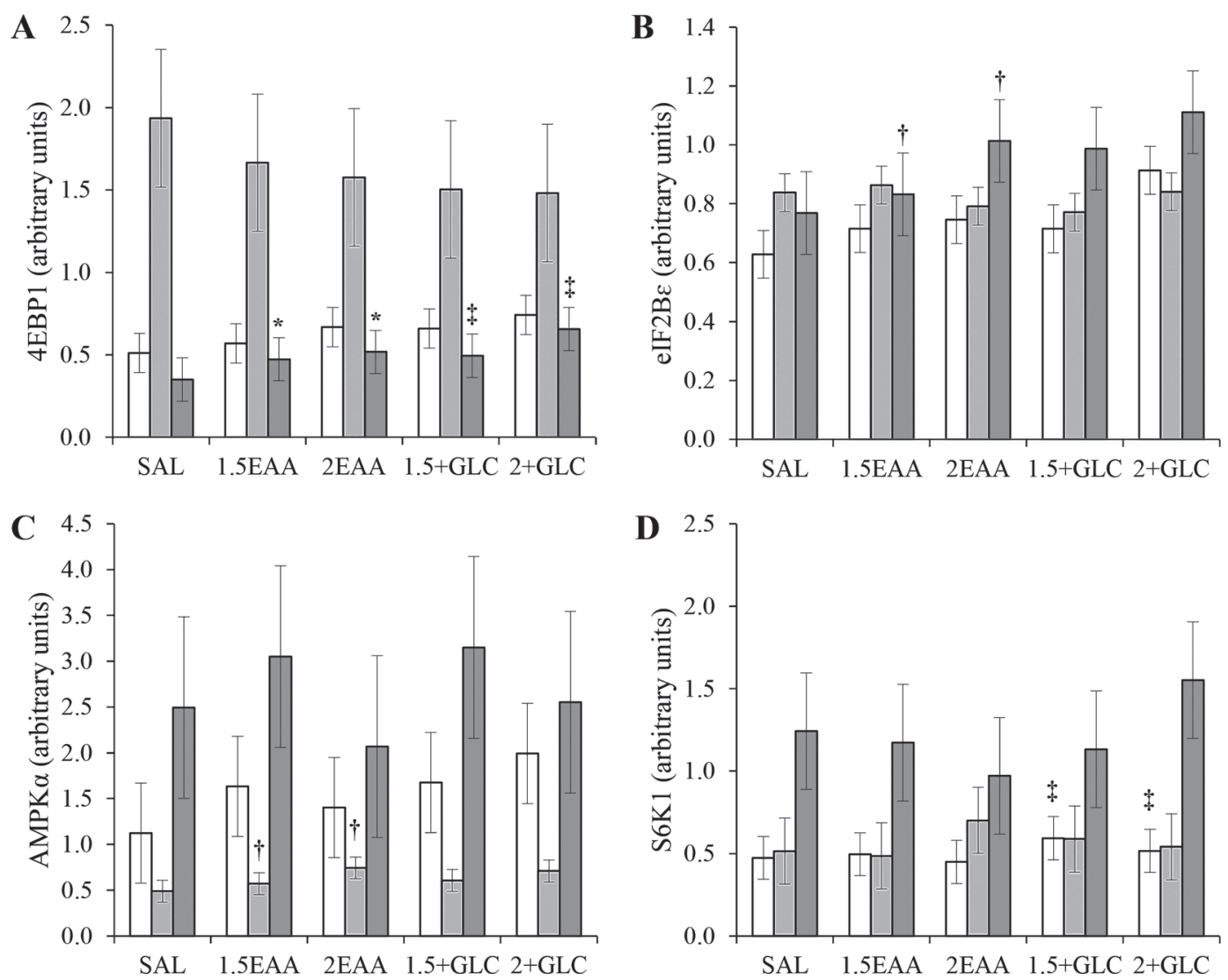

Figure 2. Protein abundances of (A) 4EBP1 (eIF4E-binding protein 1), (B) eIF2B $\varepsilon$ (eukaryotic initiation factor 2B, $\varepsilon$ subunit), (C) AMPKo (AMP-activated protein kinase, $\alpha$ subunit), and (D) S6K1 (70-kDa ribosomal protein S6 kinase) in skeletal muscle of lactating dairy cows after 5 $\mathrm{d}$ of abomasal infusion of $0.9 \%$ saline (SAL) or complete mixtures of EAA equivalent to 1,500 and 2,000 g/d casein, with or without the inclusion of $1,000 \mathrm{~g} / \mathrm{d}$ glucose $(1.5 \mathrm{EAA}, 2 \mathrm{EAA}, 1.5+\mathrm{GLC}$, and 2+GLC, respectively). Blot densities were normalized to GAPDH. The phosphorylation state of each protein was calculated as the ratio of phosphorylated to total blot densities. Values are least squares means $\pm \mathrm{SE}(\mathrm{n}=5)$. $P_{\mathrm{EAA}}=$ linear effect of EAA without GLC; $P_{\mathrm{GLC}}=$ effect of GLC. ${ }^{*} P_{\mathrm{EAA}}<0.05 ; \dagger 0.05<P_{\mathrm{EAA}} \leq 0.15 ; \ddagger 0.05<P_{\mathrm{GLC}} \leq 0.15$. 
SAL 1.5EAA 2EAA $\quad 1.5+$ GLC $2+$ GLC

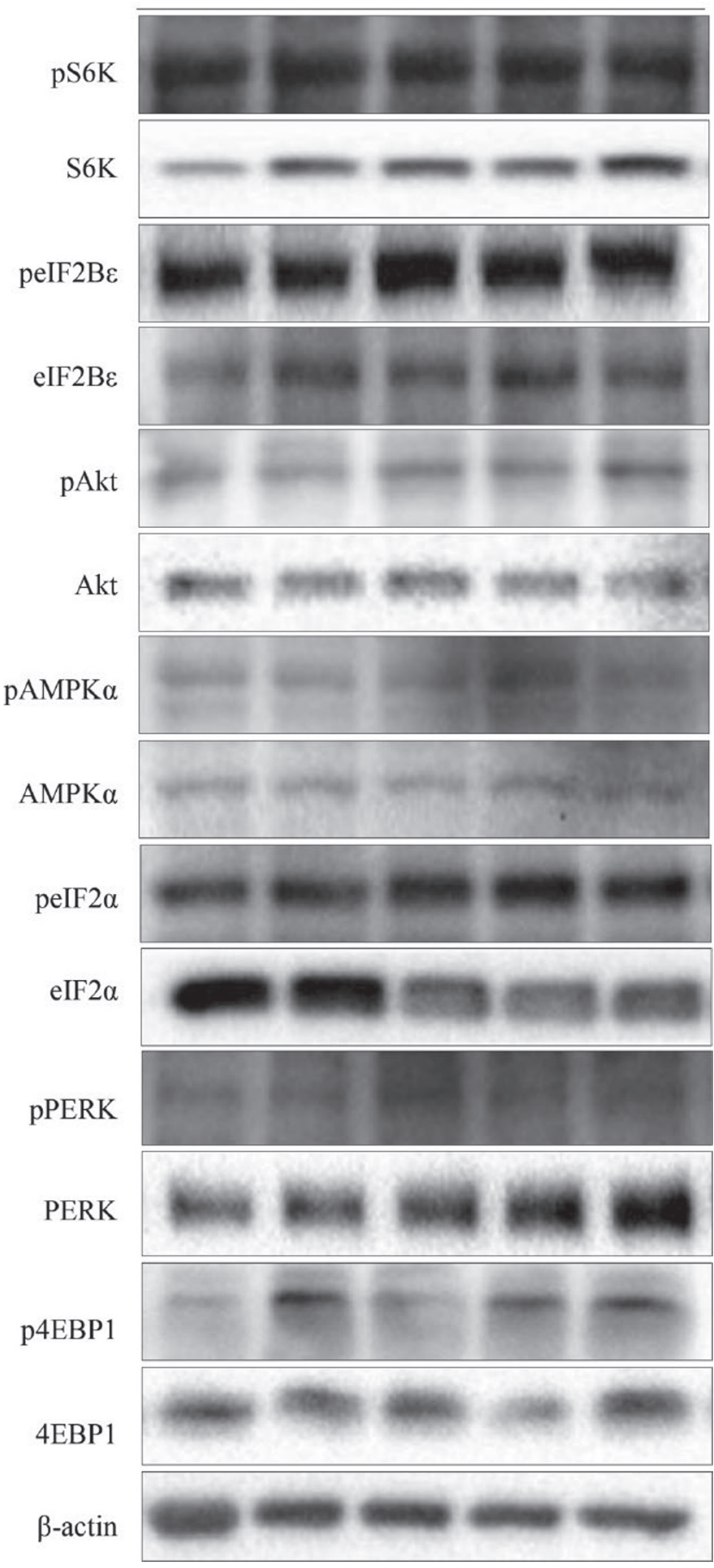

Figure 3. Representative blots for the abundance of phosphorylated (p) and total signaling proteins and $\beta$-actin from mammary tissue of lactating dairy cows after $5 \mathrm{~d}$ of abomasal infusion of $0.9 \%$ saline (SAL) or complete mixtures of EAA equivalent to 1,500 and 2,000 g/d casein, with or without the inclusion of $1.000 \mathrm{~g} / \mathrm{d}$ glucose $(1.5 \mathrm{EAA}$ 2EAA, 1.5+GLC, and 2+GLC, respectively). S6K =70-kDa ribosomal protein S6 kinase; eIF2 = eukaryotic initiation factor $2 \mathrm{~B}$, $\varepsilon$ subunit; Akt $=$ protein kinase $\mathrm{B} ; \mathrm{AMPK} \alpha=\mathrm{AMP}$-activated protein kinase $\alpha$ subunit; eIF $2 \alpha=$ eukaryotic initiation factor $2, \alpha$ subunit; PERK $=$ protein kinase RNA-like endoplasmic reticulum kinase; $4 \mathrm{EBP} 1=$ eIF4E-binding protein 1. or GLC, but EAA infusion increased the proportion of $X B P 1$ s to $X B P 1 \mathrm{u}(P=0.02)$ and $X B P 1$ s to $X B P 1 \mathrm{t}(P$ $=0.01)$. Infusion of EAA had no effect on the expression of genes related to cell turnover, but the addition of GLC increased the expression of $M Y C(P=0.05)$ and tended to increase E2F1 $(P=0.07)$ and $W_{N T 4}(P$ $=0.06)$ expression.

\section{DISCUSSION}

\section{Mammary mTORC1 Response Does Not Explain Changes in Milk Protein Yields}

The abundance and phosphorylation states of proteins involved in the regulation of mRNA translation, as well as the expression of their genes, were measured in mammary tissue to elucidate the pathway by which milk protein yield is stimulated by EAA and glucose. The mTORC1 signaling pathway integrates extracellular hormonal signals with intracellular AA and energy status to control rates of global mRNA translation in many cell types (Wullschleger et al., 2006), including those of the mammary epithelium (Moshel et al., 2006; Burgos et al., 2010; Appuhamy et al., 2011; Burgos et al., 2013). In the present study, milk protein yield increased $256 \mathrm{~g} / \mathrm{d}$ when EAA were infused for $5 \mathrm{~d}$. However, the only significant effect on mammary mTORC1 participants was an increase in total S6K1 abundance due to EAA. We previously observed an increase in mammary S6K1 abundance after $5 \mathrm{~d}$ of abomasal EAA infusion into cows (Doelman et al., 2015b) and a decrease in total S6K1 abundance after 6 d of i.v. glucose infusion into cows (Curtis et al., 2014). Both of these results, along with our current findings, support the assertion that the cellular abundance of S6K1 is responsive to nutritional manipulation. However, the regulation of S6K1 protein abundance is not an established effect of mTORC1 activation. In the current study, the expression of RPS6KB1 mRNA was not affected by EAA or glucose infusion. A cause for this discrepancy may relate to degradation of the S6K1 protein when apoptosis is activated (Dhar et al., 2009; Piedfer et al., 2013).

Previous multi-day nutrition experiments also reveal a disconnect between mammary mTORC1 activity state and milk protein yield. Abomasal EAA infusion for $5 \mathrm{~d}$ into cows at a rate equivalent to $1,000 \mathrm{~g} / \mathrm{d}$ milk protein increased the phosphorylation state of mammary S6K1 in one experiment (Doelman et al., 2015a) but not in another (Doelman et al. 2015b), despite similar increases in milk protein yield of 150 to $175 \mathrm{~g} / \mathrm{d}$. When single EAA were subtracted from the infusates, milk protein yields dropped back to control levels, even though S6K1 phosphorylation states increased to 
higher levels than observed with complete EAA infusion (Doelman et al., 2015a,b).

\section{mTORC1 in Skeletal Muscle Responds to EAA and Glucose}

In the control of flux through metabolic pathways, phosphorylation of the participating enzymes is typically a mechanism for producing rapid responses within minutes or hours of an acute perturbation, but longerterm responses over several days of chronic exposure to a perturbation are maintained by transcriptional changes in levels of enzyme expression. According to this paradigm, the lack of change in phosphorylation state of mTORC1 participants in the mammary epithelium $5 \mathrm{~d}$ after switching to a higher plane of EAA nutrition was not surprising. However, to explain the apparent lack of mammary mTORC1 stimulation, another possibility to consider is that protein synthesis in the mammary glands is regulated differently than protein synthesis in mTORC1-responsive tissues such as skeletal muscle.

The role of $\mathrm{mTORC} 1$ in the nutritional regulation of skeletal muscle protein synthesis is well characterized in non-ruminants, particularly in response to Leu and insulin under short-term treatment or postprandially (Kimball et al., 2000; O'Connor et al., 2003; Wilson et al., 2010). To our knowledge, only a single study exists investigating mTORC1 signaling in the skeletal muscle of lactating animals (Sadri et al., 2016). In our experiment, EAA increased the phosphorylation state of $4 \mathrm{EBP} 1$ in skeletal muscle, indicating activation of mTORC1, and glucose tended to increase it further, along with increasing the abundance of phosphorylated S6K1. These long-term responses were in contrast to Sadri et al. (2016), who observed no change in phos- phorylation state of $4 \mathrm{EBP} 1$ or S6K1 when an MPdeficient diet was supplemented with rumen-protected Met and His, but were in agreement with increases in phosphorylation of both $4 \mathrm{EBP} 1$ and $\mathrm{S} 6 \mathrm{~K} 1$ in the longissimus dorsi of neonatal pigs after only a $2 \mathrm{~h}$ infusion of glucose, insulin, or AA (O'Connor et al., 2003; Jeyapalan et al., 2007). Plasma insulin in our lactating cows did not change in response to glucose (Nichols et al., 2016), but the activation of mTORC1 targets in muscle suggests that an insulin-like signal was received. In contrast to findings in young, growing pigs (Davis et al., 2002), EAA alone induced a larger mTORC1 response than glucose, which may have been due in part to the propensity for skeletal muscle to decrease in insulin sensitivity as animals mature (Wray-Cahen et al., 1997; Lobley, 1998). Similarly, Bequette et al. (2002) found that protein synthesis in the hind limb of mature lactating goats was more responsive to AA than to insulin. In summary, the long-term nutritional regulation of translation through mTORC1 was not apparent in the mammary glands of lactating cows, but it was apparent in skeletal muscle.

\section{ER Homeostasis-Related Genes Suggest an Adaptive Mammary UPR in Response to EAA}

The phosphorylation cascade mediated by mTORC1 is clearly operational in mammary epithelial cells in the first minutes to hours after a nutritional perturbation (Moshel et al., 2006; Burgos et al., 2010; Toerien et al., 2010; Appuhamy et al., 2011). However, these effects do not appear to be sustained over several days as in skeletal muscle. Likewise, the phosphorylation state of mammary eIF $2 \alpha$, which is central to the ISR, was not different after $5 \mathrm{~d}$ of milk protein yield stimulation by EAA. Aside from translational regulation, chronically

Table 4. Skeletal muscle expression (arbitrary units) of genes related to mammalian target of rapamycin complex 1 (mTORC1) and the integrated stress response network in lactating dairy cows receiving abomasal infusions of EAA and glucose (GLC) for $5 \mathrm{~d}^{1}$

\begin{tabular}{|c|c|c|c|c|c|c|c|c|}
\hline \multirow[b]{2}{*}{ Gene } & \multicolumn{5}{|c|}{ Treatment $^{2}$} & \multirow[b]{2}{*}{ SEM } & \multicolumn{2}{|c|}{$P$-value ${ }^{3}$} \\
\hline & SAL & $1.5 \mathrm{EAA}$ & $2 \mathrm{EAA}$ & $1.5+\mathrm{GLC}$ & $2+\mathrm{GLC}$ & & EAA & GLC \\
\hline EIF2A & 1.09 & 0.93 & 0.96 & 1.16 & 1.11 & 0.19 & 0.53 & 0.12 \\
\hline$E I F 4 E$ & 1.18 & 0.97 & 0.86 & 1.25 & 1.33 & 0.24 & 0.34 & 0.04 \\
\hline EIF2B5 & 1.21 & 1.09 & 1.02 & 1.19 & 1.13 & 0.24 & 0.54 & 0.47 \\
\hline PRKAA1 & 1.06 & 0.81 & 1.05 & 1.08 & 1.23 & 0.21 & 0.74 & 0.12 \\
\hline RPS6KB1 & 1.00 & 0.76 & 0.91 & 0.88 & 0.92 & 0.07 & 0.22 & 0.28 \\
\hline
\end{tabular}

${ }^{1}$ Values are least squares means $(\mathrm{n}=5)$ from longissimus dorsi collected on $\mathrm{d} 5$ of each period. Fold changes in gene expression relative to SAL were calculated by the $2^{\Delta \Delta \mathrm{Ct}}$ method after normalizing to $B C K D H A$.

${ }^{2}$ Infusion treatments were $0.9 \%$ saline (SAL), or complete mixtures of EAA with the same profile as found in 1,500 and 2,000 $\mathrm{g}$ of casein according to Metcalf et al. (1996), with or without the inclusion of 1,000 $\mathrm{g}$ of glucose (1.5EAA, 2EAA, 1.5+GLC, and 2+GLC, respectively).

${ }^{3} \mathrm{EAA}=$ linear effect of EAA without GLC; GLC $=$ effect of GLC. 
SAL 1.5EAA 2EAA $1.5+$ GLC $2+$ GLC

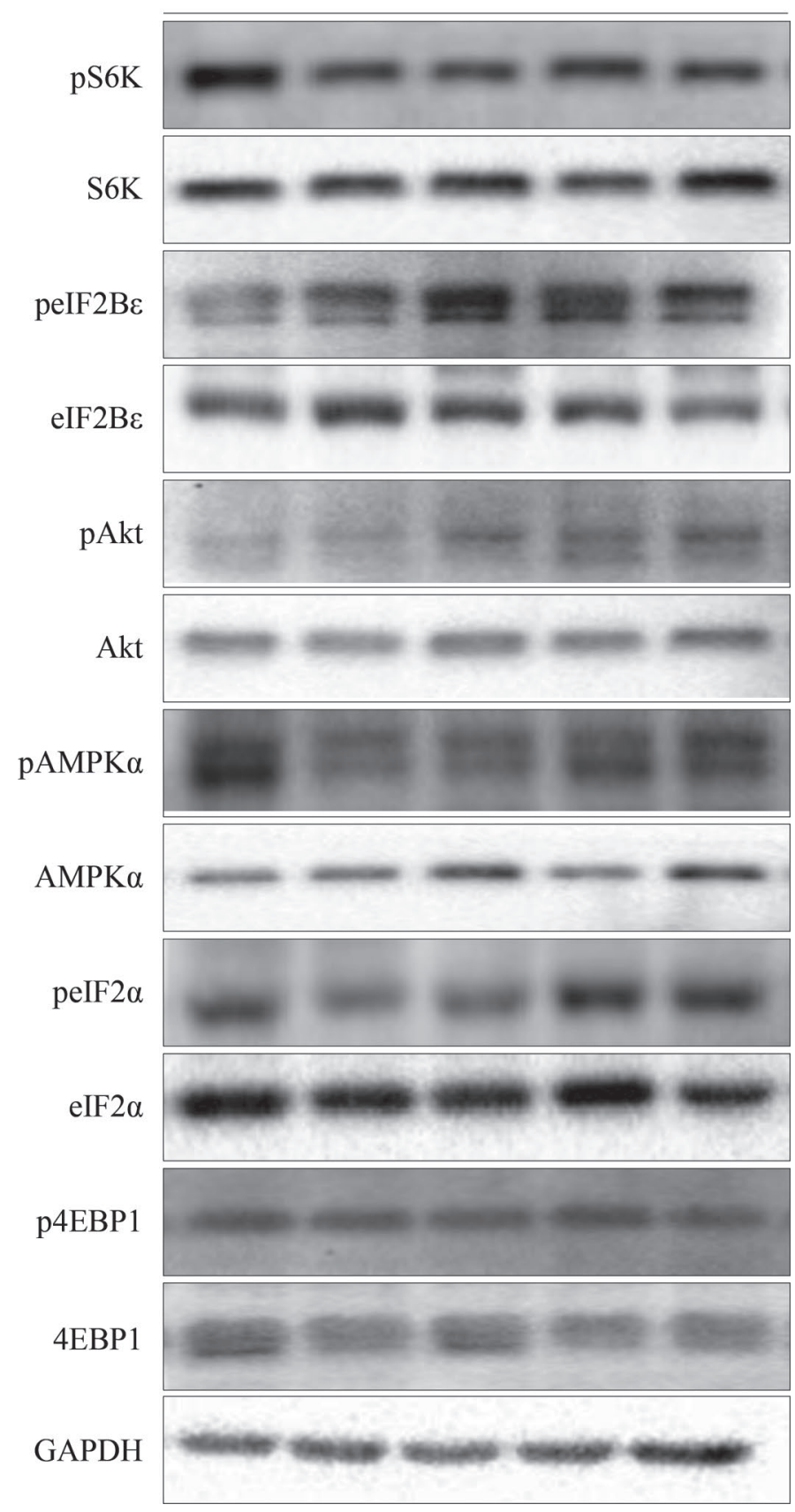

Figure 4. Representative blots for the abundance of phosphorylated (p) and total signaling proteins and GAPDH from skeletal muscle of lactating dairy cows after $5 \mathrm{~d}$ of abomasal infusion of $0.9 \%$ saline (SAL) or complete mixtures of EAA equivalent to 1,500 and 2,000 g/d casein, with or without the inclusion of $1,000 \mathrm{~g} / \mathrm{d}$ glucose (1.5EAA, 2EAA, 1.5+GLC, and 2+GLC, respectively). S6K = 70-kDa ribosomal protein S6 kinase; eIF2 = eukaryotic initiation factor 2B, $\varepsilon$ subunit; $\mathrm{Akt}=$ protein kinase $\mathrm{B} ; \mathrm{AMPK} \alpha=\mathrm{AMP}$-activated protein kinase, $\alpha$ subunit; eIF $2 \alpha=$ eukaryotic initiation factor $2, \alpha$ subunit; $4 \mathrm{EBP} 1=$ eIF4E-binding protein 1. faster milk protein synthesis could be a consequence of an increased expression of milk protein mRNA per cell, an increased number of ribosomes per cell, the increased secretory capacity of cells, or an increased mammary cell number. To investigate these 4 possibilities at the transcriptional level, we evaluated the expression of genes related to milk proteins, ribosome biogenesis, ER homeostasis, and cell turnover. The only category where we observed consistent effects of EAA was ER homeostasis.

More than half of the mass of protein synthesized by a mammary epithelial cell is destined for secretion into milk via the ER. Secretory cells, such as those of the mammary gland, the endocrine pancreas, and the gastric corpus, require a mechanism to match ER functionality with the requisite secretory activity. The UPR that was originally identified as a means of maintaining ER homeostasis in cells exposed to toxin-induced ER stress is now recognized as playing a role in cellular responses to normal, non-stress-related physiological stimuli (Rutkowski and Hegde, 2010; Hetz et al., 2015). The UPR has 3 arms, all of which are initiated by dissociation of the molecular chaperone $\mathrm{BiP}$ onto misfolded proteins from ER membrane-resident PERK, ATF6, and inositol-requiring enzyme 1 (IRE1). Then, PERK becomes phosphorylated and then phosphorylates eIF $2 \alpha$ to inhibit the eIF2B-mediated conversion of eIF2-GDP to eIF2-GTP, thereby suppressing the import of new, potentially misfolded proteins into the ER (Proud, 2005). The phosphorylation of eIF2 $\alpha$ rapidly decreases global protein synthesis, but it also stimulates translation of the transcription factor ATF4 (Kilberg et al., 2009). Two important targets of ATF4 are DDIT3, encoding the pro-apoptotic protein CHOP, and PPP1R15A, encoding GADD34 (Walter and Ron, 2011); GADD34 is a regulatory subunit of protein phosphatase $1 \mathrm{C}$ that stimulates $\mathrm{CHOP}$ to dephosphorylate eIF2 $\alpha$, counteracting the effects of PERK on eIF2B activity so that protein synthesis can resume once the ER has returned to homeostatic function. To encourage ER biogenesis, in a second arm of the UPR a cytosolic fragment of ATF6 is cleaved after BiP dissociation and enters the nucleus to activate transcription of ER-associated genes such as XBP1, DDIT3, and HSPA5, encoding BiP (Hetz et al., 2015). The third arm of the UPR is mediated by IRE1, which possesses RNase activity when phosphorylated after BiP release and excises a 26-nucleotide intron from $X B P 1 \mathrm{mRNA}$ to produce $X B P 1 \mathrm{~s}$. The product of $X B P 1 \mathrm{~s}$ translation is a transcription factor that stimulates the expression of proteins involved in differentiation of the secretory phenotype, including rough ER formation and secretory vesicle maturation (Huh et al., 2010). Mammary- 
specific deletion of the $X B P 1$ gene in mice severely curtails the increase in ER abundance and complexity that occurs in mammary epithelial cells at the onset of lactation (Davis et al., 2016). These functions of the 3 arms of the UPR serve to increase ER functionality unless the ER stress becomes too severe, at which point CHOP initiates apoptosis.

Our finding of lower expression of mammary DDIT3 and PPP1R15A during EAA infusion indicates suppression of the PERK arm of the UPR, but phosphorylation of PERK was not decreased as would be expected. The increase in $X B P 1 \mathrm{~s} / X B P 1 \mathrm{t}$ also contradicts the conclusion of UPR suppression, because XBP1 splicing is activated by the IRE1-mediated arm. However, rather than signifying ER stress (or mitigation thereof), these changes in UPR components can be interpreted as a coordinated effort to improve ER functionality, similar to what has been described for cells of the innate immune system exposed to LPS. In macrophages, stimulation of toll-like receptors by LPS causes IRE1 phosphorylation and $X B P 1$ splicing without changes in PERK phosphorylation, ATF6 cleavage, or induction of DDIT3 or HSPA5 expression, and independent of BiP- mediated IRE1 activation characteristic of the UPR (Martinon et al., 2010). Furthermore, toll-like receptor activation by LPS during tunicamycin-induced ER stress causes a decrease in DDIT3 expression but no change in HSPA5 expression, indicating suppression of specifically ATF4-mediated events. The interpretation of these LPS effects is that pathogen exposure requires an upregulation of protein secretory capacity in macrophages (inducible by $X B P 1 \mathrm{~s}$ ), but without the potential pro-apoptotic effects of CHOP (inducible by ATF4). In other words, programs embedded in the UPR that control ER biogenesis and cell death are exploited separately to effect a non-stress-related change in protein secretory capacity. Similar to the ER response to LPS in macrophages, we found that $X B P 1$ splicing increased in mammary tissue of cows given supplemental EAA, without a change in HSPA 5 expression or a decrease in ATF4-induced DDIT3 and PPP1R15A expression. Thus, we show that separate components of what is considered the UPR may be respectively upregulated and downregulated to increase ER functionality in the mammary epithelial cells of cows administered extra EAA.

Table 5. Mammary gland expression (arbitrary units) of genes for milk protein, ribosome biogenesis, endoplasmic reticulum (ER) homeostasis, and cell turnover in lactating dairy cows receiving abomasal infusions of EAA and GLC for $5 \mathrm{~d}^{1}$

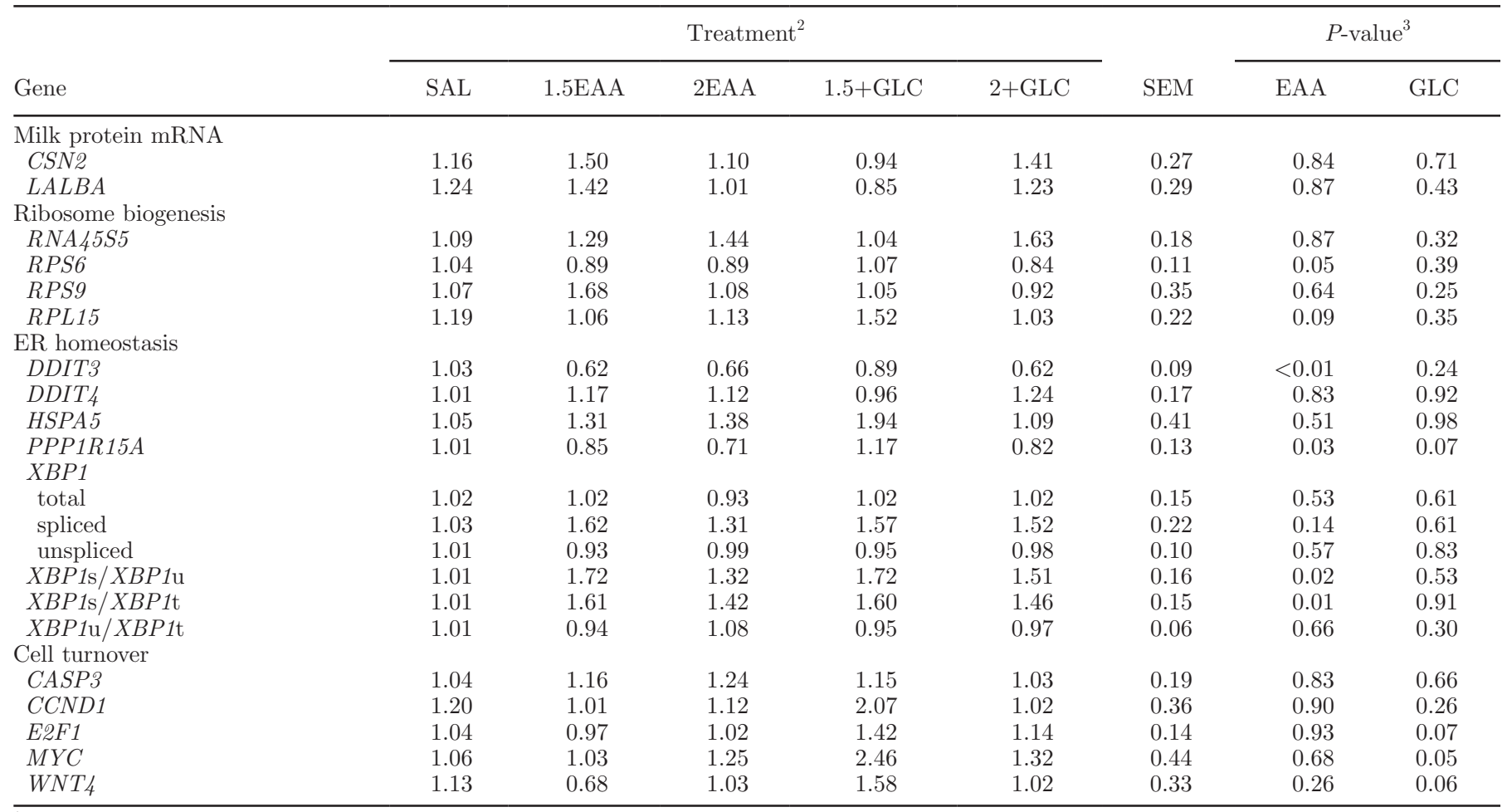

${ }^{1}$ Values are least squares means $(\mathrm{n}=5)$ from mammary tissue collected on $\mathrm{d} 5$ of each period. Fold changes in gene expression relative to SAL were calculated by the $2^{\Delta \Delta \mathrm{Ct}}$ method after normalizing to RPS6KB1.

${ }^{2}$ Infusion treatments were $0.9 \%$ saline (SAL), or complete mixtures of EAA with the same profile as found in 1,500 and 2,000 g of casein according to Metcalf et al. (1996), with or without the inclusion of 1,000 g of glucose (1.5EAA, 2EAA, 1.5+GLC, and 2+GLC, respectively).

${ }^{3} \mathrm{EAA}=$ linear effect of EAA without GLC; GLC = effect of GLC. 
How the EAA status of the lactating female is communicated to components of the mammary UPR apparatus remains to be determined. In macrophages, dephosphorylation of eIF2B $\varepsilon$ upon toll-like receptor stimulation is responsible for the suppression of PERK-induced DDIT3 expression (Woo et al., 2012). Phosphorylation of eIF2B $\varepsilon$ in mammary tissue was not reduced after $5 \mathrm{~d}$ of EAA infusion in our experiment, but the relation between eIF2B activity and ER homeostasis is a tantalizing proposition for connecting short-term translational control with long-term effects on milk protein secretion from the mammary epithelium. In previous studies, we found that EAA infusion increases the abundance of $\mathrm{eIF} 2 \mathrm{~B} \varepsilon$ protein in the mammary tissue of dairy cows (Doelman et al., 2015a,b).

Upregulation of XBP1s and downregulation of DDIT3 signifies more than an expansion of the ER. Splicing of $X B P 1$ is required for terminal differentiation of progenitor cells into cells that specialize in secretory activities, such as plasma cells that secrete antibodies (Reimold et al., 2001) and gastric zymogenic cells that secrete digestive enzymes (Huh et al., 2010). In the mammary glands, conditional knockout of XBP1 not only affected ER expansion but also suppressed proliferation and stimulated apoptosis during lactation, leading to a reduced population of epithelial cells and impairment of milk synthesis (Davis et al., 2016). Interestingly, XBP1 ablation resulted in overexpression of DDIT3, implicating XBP1 directly in the suppression of CHOP-mediated apoptosis. We selected several genes encoding proliferation and apoptosis pathways for analysis of EAA and GLC effects, because a candidate mechanism for faster protein synthesis by the mammary gland is an increase in total secretory cell number. The addition of GLC to infusates tended to increase some of these markers, but milk protein yield was not affected by GLC. Conversely, EAA infusion stimulated milk protein yield but did not affect the expression of cell turnover pathway markers. However, the effects of XBP1s and CHOP on secretory cell growth and differentiation suggest a mechanism through which improvement of EAA status of the lactating female may contribute to chronic stimulation of milk protein synthesis.

\section{CONCLUSIONS}

We found no effect of a 5-d EAA infusion on the phosphorylation state of mTORC1 targets S6K1 and 4EBP1 in mammary tissue, despite a $29 \%$ increase in milk protein yield of $256 \mathrm{~g} / \mathrm{d}$. This lack of chronic mammary mTORC1 stimulation differed from skeletal muscle, where both EAA and GLC increased the phos- phorylation state of mTORC1 targets after $5 \mathrm{~d}$. Thus, mammary mTORC1 signaling is not responsible for maintaining long-term increases in milk protein yield. Our finding that splicing of $X B P 1$ in mammary tissue increased and expression of DDIT3 and PPP1R15A decreased suggests that synthesis of milk protein was stimulated by EAA infusion through non-stress-related activation of mammary ER biogenesis and differentiation of the secretory phenotype. This study, for the first time, implicates adaptive capabilities of the UPR in the long-term nutritional regulation of milk protein yield in lactating dairy cows.

\section{ACKNOWLEDGMENTS}

We gratefully acknowledge the technical assistance of Carolyn Innes (Trouw Nutrition Agresearch). This study was financially supported by NSERC Canada (Ottawa, ON, Canada) and Trouw Nutrition Agresearch Canada (Guelph, ON, Canada).

\section{REFERENCES}

Appuhamy, J. A. D. R. N., A. L. Bell, W. A. D. Nayananjalie, J. Escobar, and M. D. Hanigan. 2011. Essential amino acids regulate both initiation and elongation of mRNA translation independent of insulin in MAC-T cells and bovine mammary tissue slices. J. Nutr. 141:1209-1215.

Bequette, B. J., C. E. Kyle, L. A. Crompton, S. E. Anderson, and M. D. Hanigan. 2002. Protein metabolism in lactating goats subjected to the insulin clamp. J. Dairy Sci. 85:1546-1555.

Burgos, S. A., M. Dai, and J. P. Cant. 2010. Nutrient availability and lactogenic hormones regulate mammary protein synthesis through the mammalian target of rapamycin signaling pathway. J. Dairy Sci. 93:153-161.

Burgos, S. A., J. J. M. Kim, M. Dai, and J. P. Cant. 2013. Energy depletion of bovine mammary epithelial cells activates AMPK and suppresses protein synthesis through inhibition of mTORC1 signaling. Horm. Metab. Res. 45:183-189.

Canadian Council on Animal Care. 2009. Guidelines on the Care and Use of Farm Animals in Research, Teaching and Testing. Canadian Council on Animal Care, Ottawa, ON, Canada.

Curtis, R. V., J. J. M. Kim, D. L. Bajramaj, J. Doelman, V. R. Osborne, and J. P. Cant. 2014. Decline in mammary translational capacity during intravenous glucose infusion into lactating dairy cows. J. Dairy Sci. 97:430-438.

Davis, K. R., S. L. Giesy, Q. Long, C. S. Krumm, K. J. Harvatine, and Y. R. Boisclair. 2016. XBP1 regulates the biosynthetic capacity of the mammary gland during lactation by controlling epithelial expansion and endoplasmic reticulum formation. Endocrinology 157:417-428.

Davis, T. A., M. L. Fiorotto, D. G. Burrin, P. J. Reeds, H. V. Nguyen, P. R. Beckett, R. C. Vann, and P. M. O'Connor. 2002. Stimulation of protein synthesis by both insulin and amino acids is unique to skeletal muscle in neonatal pigs. Am. J. Physiol. Endocrinol. Metab. 282:E880-E890.

Dhar, R., S. D. Persaud, J. R. Mireles, and A. Basu. 2009. Proteolytic cleavage of p70 ribosomal S6 kinase by caspase-3 during DNA damage-induced apoptosis. Biochemistry 48:1474-1480.

Doelman, J., R. V. Curtis, M. Carson, J. J. M. Kim, J. A. Metcalf, and J. P. Cant. 2015a. Essential amino acid infusions stimulate mammary expression of eukaryotic initiation factor $2 \mathrm{~B} \varepsilon$ but milk 
protein yield is not increased during an imbalance. J. Dairy Sci. 98:4499-4508.

Doelman, J., J. J. M. Kim, M. Carson, J. A. Metcalf, and J. P. Cant. 2015b. Branched-chain amino acid and lysine deficiencies exert different effects on mammary translational regulation. J. Dairy Sci. 98:7846-7855.

Doepel, L., and H. Lapierre. 2010. Changes in production and mammary metabolism of dairy cows in response to essential and nonessential amino acid infusions. J. Dairy Sci. 93:3264-3274.

Eisenberg, E., and E. Y. Levanon. 2013. Human housekeeping genes, revisited. Trends Genet. 29:569-574.

Hetz, C., E. Chevet, and S. A. Oakes. 2015. Proteostasis control by the unfolded protein response. Nat. Cell Biol. 17:829-838.

Huh, W. J., E. Esen, J. H. Geahlen, A. J. Bredemeyer, A.-H. Lee, G. Shi, S. F. Konieczny, L. H. Glimcher, and J. C. Mills. 2010. $\mathrm{XBP} 1$ controls maturation of gastric zymogenic cells by induction of MIST1 and expansion of the rough endoplasmic reticulum. Gastroenterology 139:2038-2049.

Jeyapalan, A. S., R. A. Orellana, A. Suryawan, P. M. J. O'Connor, H. V. Nguyen, J. Escobar, J. W. Frank, and T. A. Davis. 2007. Glucose stimulates protein synthesis in skeletal muscle of neonatal pigs through an AMPK- and mTOR-independent process. Am. J. Physiol. Endocrinol. Metab. 293:E595-E603.

Kilberg, M. S., J. Shan, and N. Su. 2009. ATF4-dependent transcription mediates signaling of amino acid limitation. Trends Endocrinol. Metab. 20:436-443.

Kimball, S. R., L. S. Jefferson, H. V. Nguyen, A. Suryawan, J. A. Bush, and T. A. Davis. 2000. Feeding stimulates protein synthesis in muscle and liver of neonatal pigs through an mTOR-dependent process. Am. J. Physiol. Endocrinol. Metab. 279:E1080-E1087.

Livak, K. J., and T. D. Schmittgen. 2001. Analysis of relative gene expression data using real-time quantitative PCR and the $2^{-\Delta \Delta C T}$ method. Methods 25:402-408.

Lobley, G. E. 1998. Nutritional and hormonal control of muscle and peripheral tissue metabolism in farm species. Livest. Prod. Sci. $56: 91-114$.

Martinon, F., X. Chen, A.-H. Lee, and L. H. Glimcher. 2010. TLR activation of the transcription factor XBP1 regulates innate immune responses in macrophages. Nat. Immunol. 11:411-418.

Metcalf, J. A., L. A. Crompton, D. Wray-Cahen, M. A. Lomax, J. D. Sutton, D. E. Beever, J. C. MacRae, B. J. Bequette, F. R. C. Backwell, and G. E. Lobley. 1996. Responses in milk constituents to intravascular administration of two mixtures of amino acids to dairy cows. J. Dairy Sci. 79:1425-1429.

Moshel, Y., R. E. Rhoads, and I. Barash. 2006. Role of amino acids in translational mechanisms governing milk protein synthesis in murine and ruminant mammary epithelial cells. J. Cell. Biochem. 98:685-700.

Nichols, K., M. Carson, J. J. M. Kim, J. A. Metcalf, J. P. Cant, and J. Doelman. 2016. Glucose supplementation stimulates peripheral branched-chain amino acid catabolism in lactating dairy cows during essential amino acid infusions. J. Dairy Sci. 99:1145-1160.
O'Connor, P. M., S. R. Kimball, A. Suryawan, J. A. Bush, H. V. Hguyen, L. S. Jefferson, and T. A. Davis. 2003. Regulation of translation initiation by insulin and amino acids in skeletal muscle of neonatal pigs. Am. J. Physiol. Endocrinol. Metab. 285:E40-E53.

O'Connor, P. M., S. R. Kimball, A. Suryawan, J. A. Bush, H. V. Hguyen, L. S. Jefferson, and T. A. Davis. 2004. Regulation of neonatal liver protein synthesis by insulin and amino acids in pigs. Am. J. Physiol. Endocrinol. Metab. 286:E994-E1003.

Piedfer, M., S. Bouchet, R. Tang, C. Billard, D. Dauzonne, and B. Bauvois. 2013. p70S6 kinase is a target of the novel proteasome inhibitor 3,3'-diamino-4'-methoxyflavone during apoptosis in human myeloid tumor cells. Biochim. Biophys. Acta 1833:1316-1328.

Proud, C. G. 2005. eIF2 and the control of cell physiology. Semin. Cell Dev. Biol. 16:3-12.

Reimold, A. M., N. N. Iwakoshi, J. Manis, P. Vallabhajosyula, E. Szomolanyi-Tsuda, E. M. Gravellese, D. Friend, M. J. Grusby, F. Alt, and L. H. Glimcher. 2001. Plasma cell differentiation requires the transcription factor XBP-1. Nature 412:300-307.

Rius, A. G., J. A. D. R. N. Appuhamy, J. Cyriac, D. Kirovski, O. Becvar, J. Escobar, M. L. McGilliard, B. J. Bequette, R. M. Akers, and M. D. Hanigan. 2010. Regulation of protein synthesis in mammary glands of lactating dairy cows by starch and amino acids. J. Dairy Sci. 93:3114-3127.

Rutkowski, D. T., and R. S. Hegde. 2010. Regulation of basal cellular physiology by the homeostatic unfolded protein response. J. Cell Biol. 189:783-794.

Sadri, H., F. Giallongo, A. N. Hristov, J. Werner, C. H. Lang, C. Parys, B. Saremi, and H. Sauerwein. 2016. Effects of slow-release urea and rumen-protected methionine and histidine on mammalian target of rapamycin (mTOR) signaling and ubiquitin proteasome-related gene expression in skeletal muscle of dairy cows. J. Dairy Sci. 99:6702-6713.

Toerien, C. A., D. R. Trout, and J. P. Cant. 2010. Nutritional stimulation of milk protein yield of cows is associated with changes in phosphorylation of mammary eukaryotic initiation factor 2 and ribosomal S6 kinase 1. J. Nutr. 140:285-292.

Walter, P., and D. Ron. 2011. The unfolded protein response: From stress pathway to homeostatic regulation. Science 334:1081-1086.

Wilson, F. A., A. Suryawan, M. C. Gazzaneo, R. A. Orellana, H. V. Nguyen, and T. A. Davis. 2010. Stimulation of muscle protein synthesis by prolonged parenteral infusion of leucine is dependent on amino acid availability in neonatal pigs. J. Nutr. 140:264-270.

Woo, C. W., L. Kutzler, S. R. Kimball, and I. Tabas. 2012. Tolllike receptor activation suppresses ER stress factor CHOP and translation inhibition through activation of eIF2B. Nat. Cell Biol. 14:192-200.

Wray-Cahen, D., P. R. Beckett, H. V. Nguyen, and T. A. Davis. 1997. Insulin-stimulated amino acid utilization during glucose and amino acid clamps decreases with development. Am. J. Physiol. 273:E305-E314.

Wullschleger, S., R. Loewith, and M. N. Hall. 2006. TOR signaling in growth and metabolism. Cell 124:471-484. 